\title{
PENERAPAN GENERATED LESSON DALAM KEGIATAN LABORATORIUM BERBASIS INKUIRI UNTUK MENGUKUR KEMAMPUAN MERANCANG PERCOBAAN PADA MATERI RESPIRASI
}

\author{
Reni Marlina $^{(1)}$, Eko Sri Wahyuni ${ }^{(2)}$, Titin $^{(3)}$ \\ Pendidikan Biologi, FKIP Universitas Tanjungpura \\ renitahak@yahoo.com
}

\begin{abstract}
The aim of this study is to measure the ability of the experimental design students PGMIPAU in the practicum General Biology.The title practicum General Biology is respiration with the implementation of inquiry based laboratory activities are generated lesson.The method used in this study was a pretest - posttest control group design. The sample in this study is a first semester student PGMIPAU the 2013/2014 school year in the practicum General Biology. The instruments used is guidance practicum, worksheet, and inquiry test by multiple choice. The results show the ability of the experimental design students PGMIPAU in the practicum General Biology with inquiry -based laboratory activities are generated lesson in the very good category is determine the type of problem have average $96 \%$. Beside that, the ability determining purpose of the experiment in the good category with average percentage $85 \%$.
\end{abstract}

Key word: inquiry based laboratory, respiration.

Biologi merupakan ilmu untuk meningkatkan pengetahuan, keterampilan, sikap, dan nilai. Biologi berkaitan dengan cara mencari tahu dan memahami alam secara sistematis. Biologi bukan hanya penguasaan kumpulan pengetahuan yang berupa fakta-fakta, konsepkonsep, prinsip-prinsip saja, tetapi juga merupakan suatu proses penemuan. Proses penemuan akan dapat diamati salah satunya dalam kegiatan praktikum. Materi-materi yang tercakup dalam praktikum disusun berdasarkan bahan kuliah sehingga memiliki keselarasan antara kegiatan praktikum dengan materi yang diperoleh dalam kuliah. Pelaksanaan kegiatan praktikum ini diharapkan memberi gambaran dan fakta yang lebih jelas sehingga mahasiswa dapat memahami konsepkonsep biologi yang lebih baik. Mahasiswa juga dapat berlatih melakukan pengamatan sebagai bagian dari penelitian. Mahasiswa program studi Pendidikan Biologi khususnya mereka yang berada di Program Pendidikan Guru MIPA berbasis Keunggulan (PGMIPAU) pada semester I, wajib mengambil mata kuliah praktikum General Biology. Mata kuliah ini membekali mahasiswa tentang pengenalan mikroskop, sel, difusi dan osmosis, fotosintesis, respirasi, genetika, anatomi tumbuhan, gerak refleks, dan analisis vegetasi. Mata kuliah ini berbobot 1 SKS.

Pola kegiatan praktikum yang selama ini dilakukan masih didominasi oleh kegiatan asisten atau 
dosen pengampu mata kuliah praktikum dengan cara membagikan panduan atau penuntun praktikum. Penggunaan penuntun praktikum yang telah tertulis lengkap kurang memberikan pengalaman kepada mahasiswa untuk melakukan proses sains. Akibatnya mahasiswa tidak memiliki keterampilan proses sains yang dapat diandalkan. Oleh karena itu, perlu adanya pembaharuan dalam hal kegiatan praktikum yang dilaksanakan. Pembaharuan ini bertujuan untuk meningkatkan keterampilan proses sains mahasiswa.

Pelaksanaan praktikum selama ini dilaksanakan secara berkelompok. Pembagian kelompok saat ini dirasakan kurang diperhatikan karena dosen pengampu mata kuliah kadangkala memberikan kebebasan kepada mahasiswa untuk berkelompok sesuai keinginannya. Ada pula beberapa dosen yang menyerahkan sepenuhnya kepada asisten praktikum untuk mengelompokkan mahasiswa dalam beberapa kelompok. Padahal pengetahuan awal mahasiswa tentang materi respirasi ini tentunya sangat beragam sehingga dilakukanlah pengelompokkan secara generated lesson. Pengelompokkan secara generated lesson ini merupakan pengelompokkan mahasiswa dengan memperhatikan kemampuan awal mahasiswa yang diukur dengan menggunakan tes awal. Jadi, mahasiswa yang memiliki kategori yang sama akan berkelompok dengan beberapa mahasiswa yang memiliki kategori sama.

Pengelompokkan secara generated lesson ini digabungkan dengan kegiatan laboratorium berbasis inkuiri. Setelah mahasiswa telah menemukan kelompok praktikum, kegiatan selanjutnya adalah meminta mahasiswa untuk membuat atau merancang suatu kegiatan praktikum atau satu jenis permasalahan yang akan dipraktikumkan. Perancangan praktikum atau percobaan ini dilakukan atau ditetapkan sendiri oleh mahasiswa sehingga dikenal dengan kegiatan laboratorium berbasis inkuiri. Dengan melaksanakan kegiatan laboratorium berbasis inkuiri ini diharapkan tiap-tiap mahasiswa yang telah berkelompok dengan kategori sama dapat menciptakan suatu ide atau menemukan suatu permasalahan yang dapat dilakukan. Permasalahan yang direncanakan untuk dipraktikumkan merupakan pengetahuan awal mahasiswa per individu tentang materi respirasi yang berhubungan langsung dengan kehidupan mahasiswa sehari-hari.

$$
\text { Kemampuan }
$$

dalam merancang percobaan yang akan diteliti pada penelitian ini berhubungan dengan kemampuan kinerja atau kerja ilmiah. Keefektifan kegiatan laboratorium berbasis inkuiri terhadap kerja ilmiah mahasiswa telah diteliti oleh Marlina (2011). Hasil penelitian menunjukkan kinerja mahasiswa calon guru biologi yang menggunakan kegiatan laboratorium berbasis inkuiri dengan memanfaatkan lingkungan lokal berbeda signifikan dengan yang menggunakan kegiatan laboratorium tradisional. Kegiatan laboratorium berbasis inkuiri berwawasan lingkungan lokal lebih memfokuskan mahasiswa sebagai subyek belajar yang telah memiliki pengetahuan awal sebelum belajar formal dan membangun pengetahuannya melalui 
kegiatan laboratorium, interaksi dengan dosen dan sesama teman. Kemampuan proses ilmiah (kinerja) kelompok yang melakukan kegiatan laboratorium berbasis inkuiri berwawasan lingkungan lokal berada pada kriteria sangat baik, sedangkan kelompok yang melakukan kegiatan laboratorium tradisional berada pada kategori kurang. Dengan demikian, revisi yang dilakukan memberikan kontribusi positif terhadap jalannya praktikum.

Berdasarkan uraian di atas, diperlukan suatu penelitian yang dapat mengukur kemampuan mahasiswa dalam merancang percobaan secara mandiri. Sehingga kegiatan praktikum lebih dapat meningkatkan kreatifitas mahasiswa dalam praktikum. Berdasarkan aturan yang tercantum dalam BSNP (2006), menyatakan bahwa proses belajar mengajar tidak hanya ditekankan pada aspek kognitif saja, tetapi juga aspek afektif dan psikomotor. Dengan demikian, peneliti berkeinginan untuk mengukur lebih jauh tentang kegiatan laboratorium berbasis inkuiri secara generated lesson untuk mengukur kemampuan mahasiswa PGMIPAU pada Mata Kuliah praktikum General Biology.dalam merancang percobaan secara mandiri.

\section{Metode}

Metode yang digunakan dalam penelitian ini adalah metode true eksperimen design dengan bentuk pretest-posttest control group design. Mahasiswa semester I pada tahun ajaran 2012/2013 dalam PGMIPAU yang mengambil mata kuliah general biology dan tidak dalam status mengulang adalah subjek dalam penelitian ini. Sebelum pelaksanaan kegiatan laboratorium berbasis inkuiri, mahasiswa diberikan tes awal (pre-test) untuk mengukur kategori kemampuan perindividu dalam menerapkan metode ilmiah. Adapun instrumen yang digunakan berupa penuntun praktikum dan soal tes berinkuiri dalam bentuk pilhan ganda. Berdasarkan hasil tes tersebut, maka diperoleh data hasil penelitian yang berupa persentase kemampuan mahasiswa dalam merancang percoaan oleh mahasiswa PGMIPAU pada praktikum General Biology pada judul acara respirasi dalam kegiatan laboratorium berbasis inkuiri secara generated lesson. Data tersebut diberikan skor dengan kriteria berikut: Item yang benar diberi skor 1 dan item yang salah diberi skor 0 . Pada pengolahan data kemampuan mahasiswa dalam merancang percobaan dilakukan dengan langkahlangkah sebagai berikut:

a.

Menyatakan skor dalam bentuk persentase dengan rumus:

$$
N P=\frac{R}{S M} \times 100 \%
$$

Keterangan:

$\mathrm{NP}=$ Persentase kemampuan

$\mathrm{R}=$ Skor yang diperoleh

$\mathrm{SM}=$ Skor maksimum (Purwanto, 1991).

b.

$$
\begin{aligned}
& \text { persentase rata-rata dengan } \\
& \text { rumus } X=\frac{\bar{\sum} X_{i}}{N} \quad \text { (Arikunto, }
\end{aligned}
$$$$
\text { 1990). }
$$

c. Menafsirkan

persentase dengan kriteria:

$86 \%$ - 100\% Sangat Baik

$76 \%-85 \%$ Baik

$60 \%-75 \%$ Cukup 
$55 \%-59 \%$ Kurang

$\leq 54 \%$
(Purwanto, 1991).

\section{Hasil dan Pembahasan}

Penerapan kegiatan laboratorium berbasis inkuiri secara generated lesson untuk mengukur kemampuan mahasiswa dalam merancang percobaan dalam acara praktikum respirasi dapat dilihat pada Gambar 1. Berdasarkan data pada Gambar 1, dapat diketahui bahwa berdasarkan 5 aspek yang diukur dalam kemampuan merancang suatu percobaan, aspek yang memperoleh persentase tertinggi adalah menentukan percobaan. Sedangkan aspek yang paling rendah adalah mengkomunikasikan hasil percobaan. Berikut akan dibahas penyebab-penyebab yang mempengaruhi rendah dan tingginya setiap aspek yang diukur dalam merancang percobaan.

Pada penelitian ini, praktikum dilaksanakan dalam $2 \mathrm{x}$ pertemuan, pertemuan pertama adalah proses persiapan dan kegiatan kedua adalah proses pelaksanaan. Pada proses persiapan, kegiatan yang dilakukan adalah pelaksanaan generated lesson dengan memberikan pre-test dan dilakukan analisis jawaban dan selanjutnya pengelompokkan mahasiswa berdasarkan kategori yang sama. Kegiatan selanjutnya adalah berdiskusi sesama anggota kelompok untuk menentukan apa yang menjadi permasalahan yang akan dipecahkan dalam kegiatan praktikum berbasis inkuiri nantinya. Kegiatan ini dibimbnig oleh dosen pengmpu mata kuliah dan juga dua orang asisten. Pembimbingan ini dimaksudkan untuk mengontrol rancangan percobaan yang kemungkinan terdapat kendala dalam pelaksanaan nantinya seperti ketersediaan alat atau tenaga ahli dalam menggunakan alatalat tertentu. Sehingga meskipun rancangan percobaan dibuat oleh mahasiswa, namun harus dikonsultasikan dahulu apakah dapat dilakukan atau tidak nantinya.

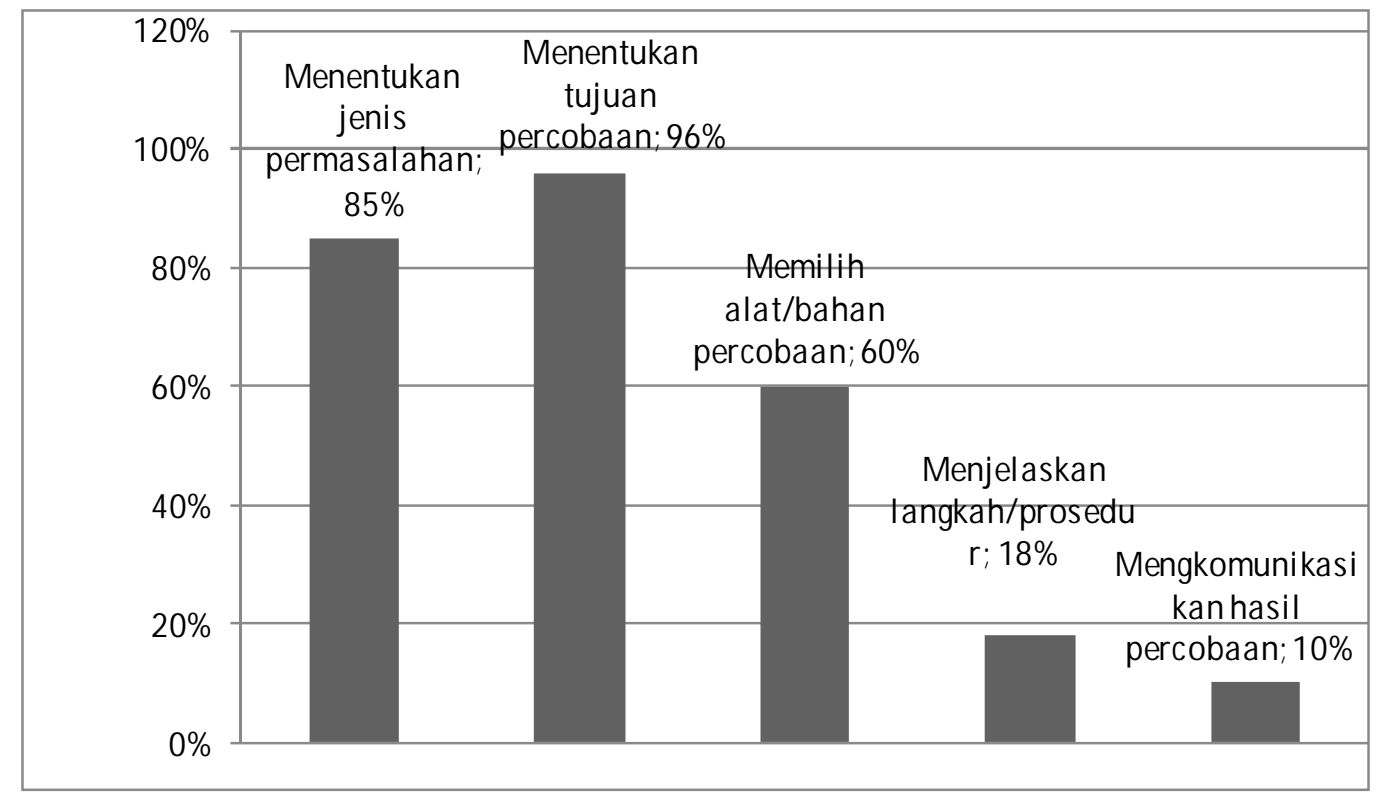


Gambar 1. Persentase kemampuan mahasiswa merancang percobaan pada materi respirasi.

Kegiatan laboratorium berbasis inkuiri adalah cara belajar mengajar untuk mengembangkan keterampilan memiliki dan memecahkan masalah dengan menggunakan pola berfikir kritis. Dengan cara ini mahasiswa diharapkan meneliti berbagai masalah sosial sehingga mereka memperoleh pengetahuan, keterampilan akademis, sikap dan nilai yang baik dan keterampilan sosial (Ahmadi, 2005). Inkuiri berpusat dimana mahasiswa dihadapkan kedalam suatu masalah kemudian mencari jawaban melalui suatu prosedur yang digariskan secara jelas dan struktural. Dengan menitik beratkan pada proses menemukan langsung oleh mahasiswa, maka penguasaan konsep dapat ditingkatkan sehingga kemampuan memecahkan masalah mahasiswa yang diharapkan juga meningkat. Keterlibatan langsung dalam proses pembelajaran diharapkan mahasiswa memiliki kecakapan hidup. Dengan kecakapan-kecakapan tersebut mahasiswa mengenal potensi-potensi diri, eksistensi diri, kecakapan berpikir baik mengali informasi, mengolah informasi, mengambil keputusan yang semuanya bermuara pada kecakapan memecahkan masalah.

Kemampuan merancang percobaan terdiri dari lima aspek. Berikut analisis kemampuan setiap indikator yang terdiri dari menentukan jenis permasalahan, menentukan tujuan percobaan, memilih alat/ bahan percobaan, menjelaskan langkah atau prosedur, dan mengkomunikasikan hasil percobaan. Dari lima aspek yang diukur, kemampuan dalam menentukan tujuan permasalahan memperoleh persentase tertinggi yaitu sebesar $96 \%$.

Hal ini disebabkan karena mahasiswa telah mampu berpikir secara logis untuk menentukan jenis permasalahan secara langsung berdasarkan hasil pengamatan dalam kehidupan sehari-hari mereka. Hal ini sejalan dengan pendapat Schmidt (dalam Admin, 2009) bahwa inkuiri adalah suatu proses untuk memperoleh dan mendapatkan informasi dengan melakukan observasi atau eksperimen untuk mencari jawaban atau memecahkan masalah terhadap masalah atau rumusan masalah dengan menggunakan kemampuan berfikir kritis dan logis.

Kemampuan merancang percobaan sangat erat kaitannya dengan salah satu keterampilan yang terdapat dalam Keterampilan Proses Sains (KPS) yaitu keterampilan meramalkan (prediksi). Keterampilan meramalkan (prediksi) ini mencakup keterampilan mengajukan perkiraan tntang sesuatu yang belum terjadi berdasarkan suatu kecenderungan atau pola yang sudah ada (Rustaman, 2005). Menurut Trinandita (dalam Yasa, 2008) menyatakan bahwa yang paling mendasar yang dituntut dalam proses praktikum adalah keaktifan peserta didik. Keaktifan peserta didik dalam pembelajaran akan menyebabkan interaksi yang tinggi antara dosen dengan peserta didik ataupun dengan peserta didik itu sendiri. Hal ini akan mengakibatkan suasana laboratorium menjadi segar dan kondusif, dimana masing-masing 
siswa akan mengakibatkan pula terbentuknya pengetahuan dan keterampilan yang akan mengarah pada peningkatan prestasi.

$\begin{array}{lr}\text { 1. Menentukan } & \text { Jenis } \\ \text { Permasalahan } & \\ \text { Bila dalam } & \text { pembelajaran } \\ \text { menampilkan materi atau }\end{array}$ informasi yang berhubungan dengan keseharian peserta didik, maka pada dirinya akan muncul rasa ingin tahu (Lumsden, 1999). Berdasarkan itu, diberikan kebebasan dalam menentukan jenis permasalahan yang berhubungan dengan keseharian mahasiswa. Kreatifitas mahasiswa dalam menentukan jenis permasalahan terlihat dari beranekaragamnya permasalahan yang dikemukakan oleh masing-masing mahasiswa dalam kelompoknya. Dalam menentukan jenis permasalahan juga bergantung pada kebiasaan berpikir mahasiswa.

Kebiasaan berpikir (habits of mind) merupakan salah satu dimensi hasil belajar jangka panjang (learning outcomes). Kebiasaan berpikir tersebut dapat dibedakan menjadi berpikir kreatif dan pengaturan diri. Irisan ketiga kebiasaan berpikir tersebut turut menentukan tingkat kepercayaan diri dan kepribadian seseorang dalam menghadapi masalah (Rustaman, 2005). Kebiasaan berpikir khususnya pada mahasiswa PGMIPAU belum pernah diukur, ini juga merupakan salah satu penyebab persentase ketercapaian kemampuan mahasiswa dalam memikirkan apa yang menjadi jenis permasalahan hanya $85 \%$. Alasan tentang belum pernah diukurnya kemampuan berpikir dikarenakan asesmen tentang kemampuan dan kebiasaan berpikir belum banyak dikembangkan. Pada bidang pendidikan sains khususnya pendidikan biologi telah dicoba dikembangkan berbagai pembelajaran untuk mengembangkan kemampuan berpikir, termasuk instrumen yang mengukur hasil belajar untuk mengembangkan kemampuan berpikir tertentu (Rustaman, 2005). Tidak jarang setiap kelompok merasa kebingungan untuk memilih salah satu jenis permasalahan yang akan dilakukan atau yang dipraktikumkan. Karena mereka menganggap semua jenis permasalahan tersebut layak untuk dipraktikumkan. Hal ini senada dengan yang dijelaskan oleh Bruner (Dahar, 1996) bahwa tujuan dari belajar tidak hanya untuk memperoleh pengetahuan saja tetapi juga suatu cara yang dapat merangsang keingintahuan peserta didik dan memotivasi kemampuan mereka untuk menemukan sesuatu. Namun ada juga satu orang mahasiswa dalam kelompok empat yang tidak memiliki ide atau memberikan kontribusi dalam kelompoknya dalam menentukan jenis permasalahan. Hal ini disebabkan karena belum terbiasanya mahasiswa tersebut dalam melakukan kegiatan praktikum yang menuntutnya untuk mengeksplorasi pengetahuan awal yang dimilikinya.

Keterbatasan kemampuan mahasiswa dalam mengemukakan permasalahan berdasarkan pengetahuan 
awalnya dapat distimulasi dengan pertanyaan-pertanyaan yang menuntun mahasiswa untuk berpikir kritis sehingga dapat memunculkan ide untuk menentukan jenis permasalahan. Jadi, dalam hal ini peran dosen pengampu mata kuliah atau asisten praktikum sangat diperlukan dalam mengarahkan mahasiswa berpikir secara kritis dan logis.

2. Menentukan

Jenis

Permasalahan

Apabila jenis permasalahan telah berhasil diprediksikan oleh kelompok mahasiswa. Setiap kelompok selanjutnya diminta untuk menentukan tujuan percobaan. Menurut Zion (2005), menentukan tujuan percobaan merupakan salah satu tahapan dalam inkuiri yang dapat dilakukan secara eksperimental. Pada kegiatan laboratorium berbasis inkuiri, tujuan percobaan ditentukan sendiri dengan diskusi sesama anggota kelompok yang telah ditentukan secara generated lesson berdasarkan permasalahan yang terjadi di lingkungan lokal mereka. Adanya diskusi memudahkan mahasiswa dalam menentukan tujuan percobaan. Hal ini senada dengan pendapat yang dikemukakan oleh Robinson (2006) bahwa diskusi bisa menyelesaikan masalah dengan lebih cepat. Pada kalimat di atas dapat diketahui bahwa tujuan percobaan ini berhubungan dengan jenis permasalahan sebelumnya dan dapat menjawab permasalahan.

$\begin{array}{cc}\text { Persentase } & \text { kemampuan } \\ \text { mahasiswa dalam } & \text { menentukan }\end{array}$

tujuan percobaan ini memperoleh persentase paling tinggi dibandingkan dengan kemampuan mahasiswa dalam menentukan jenis permasalahan, memilih alat dan bahan percobaan, menjelaskan langkah atau prosedur, dan mengkomunikasikan hasil percobaan. Berdasarkan hasil wawancara dengan 10 orang mahasiswa, 7 diantaranya menyatakan bahwa saat diminta untuk merancang percobaan, hal yang pertama kali ditulis adalah tujuan percobaan. Mereka akui penentuan jenis permasalahan didasarkan pada tujuan yang telah didapatkan sebelumnya. Hanya saja dalam menentukan tujuan percobaan ini, mereka mengalami kesulitan dalam menentukan katakata yang operasional agar nantinya dapat dilaksanakan dengan benar. Selain itu, hal yang menimbulkan kebingungan lainnya adalah ditemukannya lebih dari satu tujuan percobaan yang menurut kelompok mereka samasama penting untuk dilaksanakan. Akhirnya, yang menjadi pertimbangan dalam memutuskan satu tujuan percobaan adalah ketersediaan alat/ bahan praktikum yang akan mereka lakukan. Adanya kendala-kendala tersebut, persentase ketercapaian mahasiswa secara berkelompok dalam menentukan tujuan percobaan tidak maksimal, hanya $96 \%$.

3. Memilih Alat/ Bahan Percobaan Pada tahapan ini, kelompok mahasiswa akan melakukan kajian pustaka dan atau melakukan diskusi baik dengan asisten, dosen, maupun dengan mahasiswa dalam kelompok sendiri. Kajian pustaka 
atau diskusi yang dilakukan bertujuan untuk menyusun langkah-langkah yang dapat ditempuh dalam rangka menjawab jenis permasalahan yang telah dibuat sebelumnya. Kegiatan laboratorium berbasis inkuiri yang dibarengi dengan pembagian kelompok secara generated lesson juga mengajarkan mahasiswa untuk memiliki sikap peduli terhadap keberadaan laboratoriumnya. Khususnya dalam aspek memilih alat/bahan praktikum. indikator kemampuan mahasiswa dalam memilih alat/ bahan percobaan memiliki persentase $60 \%$ dengan kriteria cukup.

Pemilihan alat/bahan yang telah direncanakan oleh mahasiswa dengan baik dalam kelompoknya, dapat mempermudah mahasiswa dalam melaksanakan praktikum. Jika dilihat dari Lembar Kerja Mahasiswa (LKM), seluruh kelompok telah menuliskan alat dan bahan secara benar namun sebagian besar belum menuliskan jumlah dari setiap alat dan bahan yang dibutuhkan. Hal tersebut merupakan salah satu penyebab ketercapaian kemampuan mahasiswa dalam memilih alat/bahan praktikum hanya sebesar $60 \%$.

Padahal perlu diketahui oleh mahasiswa bahwa kelengkapan dalam menuliskan alat dan bahan praktikum dengan menyertakan jumlah yang dibutuhkan secara tepat sangat penting sekali. Hal ini didukung oleh pendapat Dlamini (2008) yang menyatakan bahwa kekurangan alat atau bahan dalam praktikum dapat menghambat kegiatan praktikum. Contoh penulisan alat dan bahan yang tidak menyertakan jumlah (keterangan) seperti:
1. Pipet tetes
2. Kaca Objek
3. Kaca Penutup
4. Botol Film

Sebaiknya dilengkapi dengan keterangan banyaknya jumlah yang dbutuhkan seperti:

\begin{tabular}{lll}
\hline 1. & Pipet tetes & 4 buah \\
2. & Kaca Objek & 8 buah \\
3. & Kaca Penutup & 8 buah \\
4. & Botol Film & 5 buah \\
\hline
\end{tabular}

Selama ini, kebiasaan mahasiswa saat praktikum adalah alat dan bahan telah tertera dalam penuntun praktikum secara lengkap sehingga mahasiswa tidak menentukan sendiri. Dalam hal ini mahasiswa tidak diberi kesempatan untuk mencoba menentukan sendiri alat dan bahan yang akan digunakan dalam percobaan. Hal ini dapat membentuk mahasiswa menjadi tidak kreatif. Dengan meminta mahasiswa menentukan sendiri alat dan bahan praktikum akan mengasah keterampilan memprediksi. Keterampilan memprediksi merupakan salah satu keterampilan dasar (basic skill) dalam keterampilan proses sains (KPS) yang sangat dianjurkan dalam proses pembelajaran khususnya dalam pendidikan biologi.

4. Menjelaskan langkah atau prosedur 
Kemampuan dalam menjelaskan langkah/ prosedur memerlukan penguasaan mahasiswa pada suatu jenis percobaan yang akan dilakukan. Peserta didik dapat lebih mudah menguasai dan menjelaskan langkah/ prosedur apabila didefinisikan, dituangkan dalam bentuk skema, bagan, diagram, atau gambar (Winkel, 1996). Pada kelompok eksperimen yang melakukan kegiatan laboratorium berbasis inkuiri berwawasan lingkungan lokal, indikator kemampuan mahasiswa dalam menjelaskan langkah/ prosedur memiliki persentase $79 \%$ dengan kriteria baik. Kriteria ini lebih unggul dibandingkan dengan persentase pada kelompok kontrol yang melakukan kegiatan laboratorium tradisional yang memperoleh kriteria kurang sekali dengan persentase $25 \%$.

Tidak ada satu kelompokpun yang membuat skema, bagan, diagram, atau gambar. Jadi, kemampuan mahasiswa secara keseluruhan dalam menjelaskan langkah/ prosedur tidak ada yang mencapai $100 \%$. Hal ini disebabkan karena mahasiswa terbiasa dengan praktikum menggunakan penuntun praktikum yang di dalamnya menjelaskan langkah/ prosedur secara rinci berbentuk seperti 'resep'. Sehingga mahasiswa tidak dituntut untuk terbiasa lebih kritis dan kreatif dalam menentukan dan menjelaskan langkah/ prosedur. Mahasiswa selama ini hanya dituntut untuk membuktikannya dan memberikan anggapan pada mahasiswa bahwa prosedur percobaan yang terdapat dalam penuntun praktikum bersifat mutlak kebenarannya. Didukung oleh Rustaman (2007) yang menyatakan bahwa jika menggunakan prosedur praktikum yang sudah jelas dan terarah tidak akan menantang seseorang menjadi kreatif. Hal ini yang mengakibatkan kegiatan laboratorium berbasis inkuiri lebih unggul dibandingkan dengan laboratorium tradisional.

\section{Mengkomunikasikan Hasil} Percobaan

Pada kegiatan laboratorium berbasis inkuiri secara generated lesson, indikator mengkomunikasikan hasil percobaan memiliki persentase 10\% dengan kriteria kurang sekali. Kriteria ini merupakan kriteria yang ketercapaiannya paling rendah dibandingkan dengan keempat kriteria lainnya yang diukur dalam penelitian ini. Rendahnya kemampuan ini disebabkan karena mahasiswa kurang terbiasa untuk menuliskan dan mengungkapkan ide/ pendapat yang dapat dengan mudah dipahami oleh pendengar atau pembaca. Kebiasaan mahasiswa jika diberikan tugas presentasi hanya membacakan isi dari bahan yang akan dipresentasikan. Mereka kurang mampu dalam menyampaiakn dengan menggunakan bahasanya sendiri.

Cara berkomunikasi yang efektif, jelas, dan tepat, dengan bahasa yang mudah dimengerti oleh pendengar, seharusnya perlu dilatih dan dikembangkan dalam diri peserta didik sejak dini. Karena tanpa kemampuan 
berkomunikasi yang baik, pesan yang akan disampaikan menjadi tidak sampai. Berkomunikasi yang baik diperlukan oleh setiap individu, karena setiap manusia pasti memiliki pendapat, ide, atau gagasan yang harus disampaikan kepada orang lain. Sehingga kemampuan berkomunikasi ini sangat penting untuk dilatih dan dikembangkan oleh masingmasing mahasiswa. Kegiatan laboratorium berbasis inkuiri adalah kegiatan yang memberikan kesempatan kepada mahasiswa untuk mengembangkan kemampuan sosialnya termasuk kemampuan mahasiswa berkomunikasi untuk mengeluarkan pendapat secara lisan. Hal ini dikarenakan bahwa inkuiri merupakan pembelajaran yang berorientasi pada proses, menekankan keterlibatan mahasiswa secara aktif baik fisik maupun mental dengan memecahkan berbagai permasalahan.

Proses mengkomunikasikan hasil percobaan di depan kelas dilakukan oleh seluruh kelompok. Seluruh kelompok mampu mendiskusikan hasil pengamatannya, walaupun terdapat satu kelompok yang hanya sendirian saja dalam menjawab pertanyaan dari teman kelompok lainnya. Sedangkan anggota kelompok lainnya tidak membantu. Setelah ditanyakan, mereka menyatakan bahwa"kami telah melakukan pembagian tugas dan untuk mengkomunikasikan atau presentasi di depan kelas termasuk menjawab pertanyaan adalah tugasnya."

\section{Simpulan dan Saran}

Kemampuan mahasiswa dalam merancang percobaan berada pada kategori sangat baik adalah kemampuan dalam menentukan tujuan permasalahan dengan persentase rata-rata $96 \%$. Selain itu kemampuan dalam menentukan tujuan percobaan berada pada kategori baik sebesar $85 \%$. Berdasarkan hasil penelitian juga dapat disimpulkan bahwa mahasiswa dinyatakan berada pada kategori cukup dalam memilih alat/ bahan percobaan namun kurang sekali dalam mengkomunikasikan hasil percobaan dan dalam menjelaskan prosedur kerja dengan persentase masing-masing hanya sebesar $10 \%$ dan $18 \%$.

1 .

Disarankan

kepada peneliti selanjutnya untuk melakukan penelitian tentang kegiatan laboratorium berbasis inkuiri pada materi biologi lainnya.

2.

$$
\text { Kegiatan }
$$

laboratorium berbasis inkuiri dapat pula dilakukan untuk mengukur keseluruhan Keterampilan Proses Sains baik pada tingkat dasar (basic skill) maupun pada tingkat terintegrasi (integrated skill).

\section{Daftar Pustaka}

Admin. 2009. Model Pembelajaran Inkuiri. http : //agungprudent Wordpress. com/2009/05/16/trackback, diakses 7 Desember 2009.

Ahmadi, A. 2005. Strategi Belajar Mengajar. Bandung : Pustaka Setia. 
Arikunto, S. (1990). Prosedur Penelitian Suatu Pendekatan Praktek. Jakarta: Rineka Cipta.

Badan Standar Nasional Pendidikan. (2006). Buku Panduan Penyusunan KTSP, Jakarta: Depdiknas.

Dlamini,A.P. (2008). Teaching of Scientific Investigtions by Life and Natural Science Educators in Bushbuckridge. Thesis of Master Natural Science Education University of Soth Africa. Tersedia:http://pareonline.ne $t / g$ enpare. asp $? w h=0 \& a b t=1$ [10 November 2009].

Dahar, R.W. (1996). Teori-Teori Belajar. Jakarta: Erlangga.

Lumsden, L. (1999). Student Motivation. USA. University of Oregon.

Marlina (2011). Pemanfaatan Lingkunga Lokal dalam Kegiatan laboratorium Berbasis Inkuiri Terhadap Kinerja Mahasiswa Calon Guru Biologi. Jurnal Pendidikan Matematika dan IPA. 2 (2). 28 - 35.

Purwanto, M.N. (1991). PrinsipPrinsip dan Teknik Evaluasi Pengajaran. Bandung: P.T. Remaja Rosdakarya.
Robinson,C. (2006). Advance Organizers as Preparation for Small and Large Group Discussion [Online] Tersedia: http://www.Small+and+Larg e+Group+Discussion\&Spell [10 November 2012].

Rustaman, N., Dirjosoemarto, S., Ahmad Y., Yudianto, S.A., Rochintaniawati, D., Nuryani, K.M., dan Subekti, R. (2005). Strategi Belajar Mengajar Biologi. Bandung: JICA.

Rustaman, A \& Wulan, A.R. (2007). Strategi pembelajaran Biologi. Bandung. Universitas terbuka.

Winkel, W.S. (1996). Psikologi Pengajaran. Jakarta: Erlangga.

Yasa, D. 2008. Aktivitas dan Prestasi Belajar. (http: //ipotes. Wordpress. Com), diakses 24 Mei 2008.

Zion, W. (2005). The effects of metacognitive instruction embedded within an asynchronous learning network on scientific inquiry skills. International Journal of Science Education. 27 (8). 